\title{
Effect of Solvent on the Spectroscopic, Electrochemical and Spectroelectrochemical Properties of Near-Infrared Oxovanadium(IV) $\alpha, \alpha^{\prime}$-Octapentoxyphthalocyanine
}

\author{
Minzhi Li, Xu Liang, ${ }^{@ 1} \mathrm{Yu}$ Jiang, Li Xu, Qi Zhang, ${ }^{@ 2}$ and Weihua Zhu ${ }^{@ 3}$ \\ School of Chemistry and Chemical Engineering, Jiangsu University, Zhenjiang 212013, China \\ ${ }^{\circledR 1}$ E-mail: liangxuujs@126.com \\ ${ }^{\circledR 2}$ E-mail: qzhang@ujs.edu.cn,Tel: +86-511-8261-1886 \\ ${ }^{\circledR 3}$ E-mail: sayman@ujs.edu.cn,Tel:+86 511-8879-1928
}

\begin{abstract}
A near-infrared oxovanadium(IV)- $\alpha, \alpha$ '-octapentoxyphthalocyanine (oxo-V(IV)-Pc) has been synthesized and characterized. Solvent-dependent optically spectroscopic and electrochemical investigations including UV-vis absorption and magnetic circular dichroism (MCD) spectroscopy, cyclic voltammetry (CV), DPV and multi-scan rate CV electrochemistry measurements were carried out to give in-depth understanding of the electronic structure of this oxo-V(IV)-Pc. Both $\alpha, \alpha$ '-substituents and solvent polarities have large influence on the electronic structure of this NIR absorbed oxovanadium(IV)-phthalocyanine.
\end{abstract}

Keywords: Phthalocyanine, oxovanadium complexes, near infrared absorption, solvent polarity, magnetic circular dichroism, cyclic voltammetry, spectroelectrochemistry.

\section{Влияние растворителя на спектральные, электрохимические и спектроэлектрохимические свойства $\alpha, \alpha^{\prime}-$ октапентоксифталоцианината оксованадия(IV), поглощающего в ближней ИК области}

\author{
М. Аи, К. Аианг, Ю. Ажанг, А. Ксу, К. Жанг, В. Жу \\ Школа химии и химической технологии, Цзянсу университет, Чжэньизяне 212013, Китай
}

В работе получен и охарактеризован оксованадий(IV)- $\alpha, \alpha$ '-октапентоксифталоциианин, поглощзающий в ближней ИК области. С помощьью спектральных и электрохимичских методов, включая спектроскопию электронного поглощения и магнитного кругового дихроизма, ичиклическую вольтамперометрию, дифференичиальную пульсируюшую вольтамперометрию, было показано, что природа $\alpha, \alpha$ '-заместителей и полярность растворителя оказывают значительное влияние на электронную структуру полученного комплекса.

Ключевые слова: Фталоцианин, комплексы оксованадия, поглощение в ближней ИК области, полярность растворителя, магнитный круговой дихроизм, циклическая вольтамперометрия, спектроэлектрохимия. 


\section{Introduction}

Currently, there are increased research interests in phthalocyanines (Pcs) including fundamental theories to industrial applications. ${ }^{[1]}$ The large $\pi$-system of phthalocyanines can lead to strong absorption and emission in the red/ near-infrared (NIR) region, and exhibit relatively high molar extinction of the lowest energy $\pi \rightarrow \pi^{*}$ band (usually referred to as the $\mathrm{Q}$ band), which is considerably more intense than the corresponding bands in the spectra of porphyrins and tetraazaporphyrins. ${ }^{[2]}$ Although the red-shift of the Q bands of phthalocyanine can be achieved to longer wavelength region through fused-ring-expansion with benzene rings to form naphthalocyanine $(\mathrm{Nc})^{[3]}$ and then anthracocyanine (Ac) ${ }^{[4]}$ the significant destabilization of HOMO level makes these compounds unstable. Additionally, the absence of peripheral substituents are also issues with solubility. In contrast, Pcs with substituents at both peripheral $(\beta-)$ and non-peripheral $(\alpha-)$ positions generally exhibit enhanced solubility, especially the $\alpha$-substituted Pcs revealed more satisfied results due to its deformed molecular structures. ${ }^{[5]}$ On the other hand, introduction of electron donating substituents at $\alpha$-positions results in a greater destabilization of the highest occupied molecular orbital (HOMO) state relative to the lowest unoccupied molecular orbital (LUMO) state leading to the redshift of the Q band absorption in metallophthalocyanines (MPcs) and hence lower first oxidation potentials, since there are large MO coefficients at these positions in the HOMO of the $\pi$-system. ${ }^{[6]}$ NIR phthalocyanines have excellent light, weather and thermal resistances, and these complexes find use in optical recording materials, liquid crystal display devices and IR radiation filters. ${ }^{[7]}$ Oxovanadium(IV)-phthalocyanines, the high-valence metallo-phthalocyanines have various potential applications such as optical active materials, non-linear optical materials and catalysis, ${ }^{[8]}$ but solvent dependent spectroscopic and electrochemical investigations have never been described before. In this paper, the solventdependent UV-vis, magnetic cicular dichroism (MCD) spectra, cyclic voltammetry (CV), DPV and thin-layer spectroelectrochemistry will be described. The solvent-dependent spectroscopic, electrochemical and spectroelectrochemical properties indicate the polarities of the solvents have large effect on the electronic structure of NIR electron-rich, highvalence oxovanadium(IV)phthalocyanine.

\section{Experimental}

\section{Chemicals}

Analytical pure $N, N$-dimethylmethaneamide (DMF) for electrochemical measurements was purchased from the Aladdin Reagent Company of Shanghai, and freshly distilled before use. All other chemicals and solvents were analytical pure grade and were purchased from the Shanghai Guoyao Company. All solvents were dried and distilled prior to use.

\section{Materials and Instruments}

${ }^{1} \mathrm{H}$ NMR spectra were recorded on a Bruker AVANCE 400 spectrometer (operating at $400.13 \mathrm{MHz}$ ) using the residual solvent as an internal reference for ${ }^{1} \mathrm{H}\left(\delta=5.32 \mathrm{ppm}\right.$ for $\left.\mathrm{CD}_{2} \mathrm{Cl}_{2}\right)$. Cyclic voltammetry was performed in a three-electrode cell using Chi-730D electrochemistry station. A glassy carbon disk electrode was utilized as the working electrode while a platinum wire and a saturated calomel electrode (SCE) were employed as the counter and reference electrodes, respectively. An "H" type cell with a fritted glass layer to separate the cathodic and anodic sections of the cell was used during bulk electrolysis. The working and counter electrodes were made from platinum mesh and the reference electrode was an SCE. The working and reference electrodes were placed in one compartment while the counter electrode was placed in the other. UV-visible absorption spectra were recorded with a HP 8453A diode array spectrophotometer. All of the electrochemical measurements were carried out under a nitrogen atmosphere. Magnetic circular dichroism (MCD) spectra were measured with a JASCO J-815 equipped with a $1.6 \mathrm{~T}$ (tesla) permanent magnet by using both the parallel and anti-parallel fields. The conventions of Piepho and Schatz are used to describe MCD intensity and the Faraday terms. ${ }^{[9]}$ Spectral pure grade $o$-dichlorobenzene, $\mathrm{CH}_{2} \mathrm{Cl}_{2}$ and DMF for spectroscopic and electrochemical measurements was purchased from the Aladdin reagent company of Shanghai. Other chemicals and solvents were of analytical pure grade and were obtained from the Shanghai Guoyao Co. which were dried or distilled prior to use.

\section{Syntheses}

Synthesis of 3,6-dipentoxyphthalonitrile. 3,6-Dihydroxyphthalonitrile ( $1.6 \mathrm{~g}, 10 \mathrm{mmol}$ ) was added to $20 \mathrm{~mL}$ of a dry acetone solution containing 1-iodopentane ( $4.4 \mathrm{~g}, 22 \mathrm{mmol}, 2.2$ eq.) and $\mathrm{K}_{2} \mathrm{CO}_{3}(5.5 \mathrm{~g}, 40 \mathrm{mmol}, 4.0 \mathrm{eq})$. The resulting mixture was gradually heated to $60^{\circ} \mathrm{C}$, and the temperature was maintained for $4 \mathrm{~h}$. After removal of the solvent, the reaction mixture was purified by silica gel column chromatography with $\mathrm{CHCl}_{3}$ as the eluent. Recrystallization from $\mathrm{CHCl}_{3}$ and $\mathrm{MeOH}$ provided 3,6-dipentoxyphthalonitrile as a white solid compound in $88 \%$ yield $(2.64 \mathrm{~g})$. ${ }^{1} \mathrm{H}$ NMR (400 $\left.\mathrm{MHz}, \mathrm{CDCl}_{3}\right) \delta$ ppm: 7.15 (s, 2H; $\beta$-phenyl), 4.04 (t, $J=8.0 \mathrm{~Hz}, 4 \mathrm{H}$; $\left.-\mathrm{OCH}_{2}-\right), 1.84\left(\mathrm{dd}, J_{1}=12.0 \mathrm{~Hz}, J_{2}=8.0 \mathrm{~Hz}, 4 \mathrm{H} ;-\mathrm{CH}_{2}-\right), 1.49-1.35(\mathrm{~m}$, $\left.8 \mathrm{H},-\mathrm{CH}_{2} \mathrm{CH}_{2}-\right), 0.93$ (t, $J=8.0 \mathrm{~Hz}, 6 \mathrm{H} ;-\mathrm{CH}_{3}$ ).

Synthesis of $\alpha, \alpha^{\prime}$-n-octapentoxyphthalocyanine $\left(\mathrm{H}_{2} \mathrm{Pc}\right)$. Lithium $(56 \mathrm{mg}, 8.0 \mathrm{mmol})$ was added to $6 \mathrm{~mL}$ of freshly distilled 1-butanol, and the solution was stirred and heated at $150{ }^{\circ} \mathrm{C}$ under an $\mathrm{N}_{2}$ atmosphere until the lithium was completely dissolved. 3,6-Dipentoxyphthalonitrile $(300 \mathrm{mg}, 1.0 \mathrm{mmol}$ ) was then added and the resulting mixture was gradually heated at $160{ }^{\circ} \mathrm{C}$, and the temperature was maintained for $2 \mathrm{~h}$. After removal of the solvent, the reaction mixture was purified by silica gel column chromatography with $\mathrm{CHCl}_{3}: \mathrm{MeOH}(100: 3)$ as the eluent. Recrystallization from $\mathrm{CHCl}_{3}$ and $\mathrm{MeOH}$ provided the target compound, as a green solid in $63 \%$ yield $(2.64 \mathrm{~g}$ ). MALDI-TOF-MS: $m / z=1203.78$ (Calcd. for $\left.\mathrm{C}_{72} \mathrm{H}_{98} \mathrm{~N}_{8} \mathrm{O}_{8}[\mathrm{M}+\mathrm{H}]^{+}=1203.70\right) .{ }^{1} \mathrm{H} \mathrm{NMR}\left(500 \mathrm{MHz}, \mathrm{CD}_{2} \mathrm{Cl}_{2}\right) \delta \mathrm{ppm}$ : 7.49 (m, 8H; $\beta$-phenyl), 4.82 (m, 16H; - $\left.\mathrm{OCH}_{2}-\right), 2.19$ (m, 16H; - $\left.\mathrm{CH}_{2}-\right)$, 1.64-1.48 (m, 32H, $\left.-\mathrm{CH}_{2} \mathrm{CH}_{2}-\right), 1.09-0.85\left(\mathrm{~m}, 24 \mathrm{H} ;-\mathrm{CH}_{3}\right)$.

Synthesis of oxo- $V(I V)-\alpha, \alpha$ '-octapentoxyphthalocyanine (oxo$V(I V) P c, 1)$. Following the method reported by Leznoff ${ }^{10]}$ and Kasuga $^{[11]}$ cyclic tetramerization of $\alpha, \alpha^{\prime}$-pentoxyphthalonitrile, and a metal insertion reaction with $\mathrm{V}_{2} \mathrm{O}_{5}$ in molten urea gave oxo-V(IV) Pc quite easily in a yield $35.6 \%$, and the structure was confirmed by MALDI-TOF-mass and ${ }^{~} \mathrm{H}$ NMR spectra (Figure 1). MALDITOF-mass: $m / z=1269.13\left(\right.$ Calcd. $\left.[\mathrm{M}+\mathrm{H}]^{+}=1269.52\right) .{ }^{1} \mathrm{H}$ NMR $\left(\mathrm{CD}_{2} \mathrm{Cl}_{2}, 298 \mathrm{~K}\right) \delta$ ppm: 8.52 (br s, $8 \mathrm{H} ; \beta, \beta$ '-H), 4.94 (br s, $16 \mathrm{H}$; $-\mathrm{OCH}_{2}{ }^{-}$), 2.29 (br s, $16 \mathrm{H} ;-\mathrm{CH}_{2}{ }^{-}$), $1.69 \sim 1.52$ (br s, $32 \mathrm{H} ;-\mathrm{CH}_{2}-$ ), 1.02 (br s, 24H; $-\mathrm{CH}_{3}$ ).

\section{Results and Discussion}

\section{Solvent Dependent Spectroscopy}

The spectroscopic properties of oxo-V(IV)Pc in both low-polar solvent $\mathrm{CH}_{2} \mathrm{Cl}_{2}$ and polar solvent DMF are shown 
in Figure 2. The UV-vis spectra of $\mathbf{1}$ is characteristic sharp of metallo-phthalocyanines, but the $\mathrm{Q}$ bands lie at a significantly longer wavelength than those of normal oxo-V(IV)Pcs without substituent groups $\left(\lambda=695 \mathrm{~nm}\right.$ in chlorobenzene). ${ }^{[12]}$ In the low-polar solvent $\mathrm{CH}_{2} \mathrm{Cl}_{2}$ (Figure 2, left, bottom), the Q-band absorption of oxo-V(IV)Pc exhibits main absorption bands at 788 and $703 \mathrm{~nm}$. The Soret band of $\mathbf{1}$ appears at 338 $\mathrm{nm}$, and an extra band at $479 \mathrm{~nm}$ can be assigned as intramolecular charge-transfer band. In the case of oxo-V(IV)Pc in DMF (Figure 2, right, bottom), the Q-band absorption exhibits a mirror red-shift to $792 \mathrm{~nm}$. Similarly, the Soret band appears at $349 \mathrm{~nm}$ and the charge transfer band appears at $473 \mathrm{~nm}$. On the other hand, the magnetic cicular dichroism (MCD) spectra of oxo-V(IV)Pc is also typical of metallophthalocyanines, ${ }^{[13]}$ showing a clear Faraday $A$-term type of curve associated with the $\mathrm{Q}_{00}$ absorption peak at $\lambda=788 \mathrm{~nm}$ in $\mathrm{CH}_{2} \mathrm{Cl}_{2}$ (Figure 2). In the Soret band region, three bands were observed at $\lambda=336,358$ and $498 \mathrm{~nm}$, and the additional band at around $490 \mathrm{~nm}$ can be plausibly assigned to a transition involving the ether oxygen lone pairs $n-\pi^{*}$ transition. ${ }^{[14]}$ Similar shape of the MCD signals of oxo-V(IV)Pc in DMF were observed, but slightly shifted to the longer wavelength region. The assigned Faraday $A$-term type of curve associated with the $\mathrm{Q}_{00}$ absorption peak at $\lambda=792 \mathrm{~nm}$ in DMF was detected (Figure 2), and Soret bands were appeared at $\lambda=323,369$ and $410 \mathrm{~nm}$, respectively. Solvent dependent UV-vis measurements (Figure 3 ) were also carried in various organic solvents containing different solvent polarities, including $\mathrm{CH}_{2} \mathrm{Cl}_{2}$, toluene, ethylacetate, DMF and benzonitrile in order to further insight understand the solvent dependent spectroscopic properties of this oxo-V(IV)Pc 1. It is known that the red-shift of the Q-band absorptions is a function of the solvent's refractive index, ${ }^{[15]}$ and Table 1 also shows the red-shift of the Q-band absorptions based on the increase of the solvent polarities.

\section{Solvent Dependent Electrochemistry}

Electrochemical measurements were performed to give further in-depth understand of the electronic properties of this $\alpha, \alpha^{\prime}$-substituted phthalocyanines, since it is well established that the HOMO and LUMO energies of phthalocyanine derivatives correlate well with their first oxidation and reduction potentials. Electrochemical measurements were carried out in low-polar solvent $o$-dichlorobenzene and polar solvent DMF containing $0.1 \mathrm{M}$ TBAP to gain further insight into the electronic properties, and the redox potentials $E_{1 / 2}$ values derived cyclic and differential pulse voltammetry (CV and DPV) measurements. The voltammograms for oxo-V(IV) Pc in low-polar $o$-dichlorobenzene (Figure 4) contain two reversible one-electron reduction steps at $E_{1 / 2}=-0.71 \mathrm{~V}$ for [oxo-V(IV)Pc]/[oxo-V(III)Pc] , and at $E_{1 / 2}=-1.06 \mathrm{~V}$ for the ring reduction [oxo-V(III)Pc] $]^{-/}[\mathrm{oxo}-\mathrm{V}(\mathrm{III}) \mathrm{Pc}]^{2-}$, respectively, under these experimental conditions. One more irreversible reduction at $E_{1 / 2}=-1.85 \mathrm{~V}$ derived from DPV measurement can be assigned as further ring reduction [oxo-V(III)Pc] ${ }^{2-}$ $\left[\right.$ oxo-V(III)Pc] ${ }^{3-}$. Additionally, two reversible one-electron oxidation curves are also observed at $E_{1 / 2}=0.64$ and $1.03 \mathrm{~V}$ assigned as the ring oxidation [oxo-V(IV)Pc]/[oxo-V(IV) $\mathrm{Pc}^{+}$and [oxo-V(IV)Pc $]^{+} /[\mathrm{oxo}-\mathrm{V}(\mathrm{IV}) \mathrm{Pc}]^{2+}$ for $1^{\text {st }}$ and $2^{\text {nd }}$ oxidation steps, respectively. More interesting, the voltammo- grams for oxo-V(IV)Pc in polar solvent DMF (Figure 4) exhibit similar shape of the spectra, but the oxo-V(IV)Pc complex is more easily reached the $1^{\text {st }}$ oxidation and $1^{\text {st }}$ reduction processes, at $0.58 \mathrm{~V}$ and $-0.67 \mathrm{~V}$, respectively. The energy difference between the $1^{\text {st }}$ oxidation and $1^{\text {st }}$ reduction in polar DMF solution is smaller than that in low-polar $o$-DCB during the $\mathrm{CV}$ measurements (Scheme 2), that is also reflected in the red-shift of the main absorption band in polar solvents during the optically spectroscopic measurements. Compared with other vanadium phthalocyanines reported previously, this oxo-V(IV)Pc 1 with electron donating substituents introduced at $\alpha, \alpha^{\prime}$-positions, is easily oxidized than the complexes without electron donating groups at $\alpha, \alpha^{\prime}$-positions (Table 2 ). The $i_{\mathrm{p}}^{\text {Red }}$ and $i_{\mathrm{p}}^{\text {Ox }}$ values, determined from CV measurements of 1 made at various scan-rates from $10-500 \mathrm{mV}$ in both low-polar $\mathrm{CH}_{2} \mathrm{Cl}_{2}$ and polar DMF (Figure 5), provide an insight into the reversibility of the system on an experimental time-scale. The good linear correlations observed for plots of peak current versus $\mathrm{v}^{1} / 2$ for oxo-V(IV)Pc (Figure 6) confirm that all of the oxidation and reduction processes are diffusion controlled.

\section{Solvent Dependent Spectroelectrochemistry}

In order to confirm further the effect of the solvent polarities on the spectroelectrochemistry properties, thin-layer UV-visible spetra during the first and second reduction and/ or oxidation of oxo-V(IV)Pc 1 were carried out in both low polar solvent $o$-dichlorobenzene and polar solvent DMF. The comparison of spectral changes at different potential values for reversible processes were shown in Figure 7. During the first reduction process, the electroreduced oxo-V(IV)Pc 1 reveals the significant decrease of the main absorption band (Q-band), but the further increase of the additional bands in the visible region in the DMF solution. In addition to measure the spetral changes of further electroreduced oxoV(IV)Pc 1, the changes were only observed in the DMF measurements, and this clearly show that the solvent effects have large influence on the electroreduced spetral changes. The electrooxidazed spetral changes were also measuremed in both $o$-dichlorobenzene and DMF, no significant difference was observed based on the different solvent measurements. Since the $2^{\text {nd }}$ oxidation process of $\mathbf{1}$ in DMF is irreversible, thus the spetroelectrochemistry was not further proceded under this experiment conditions.

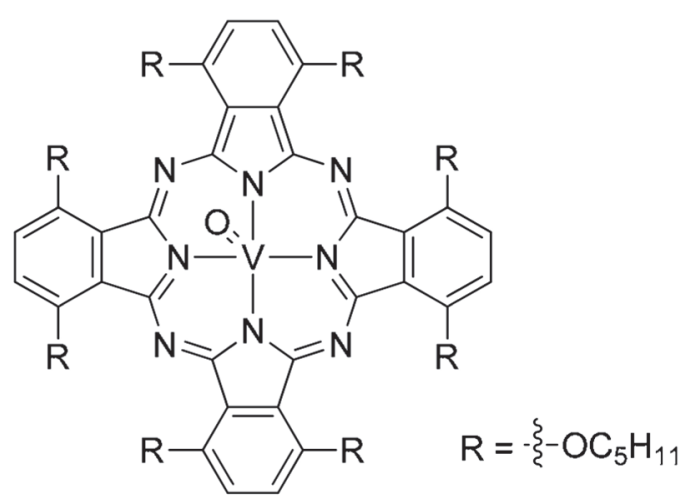

Scheme 1. Molecular structure of oxo-V(IV)Pc. 


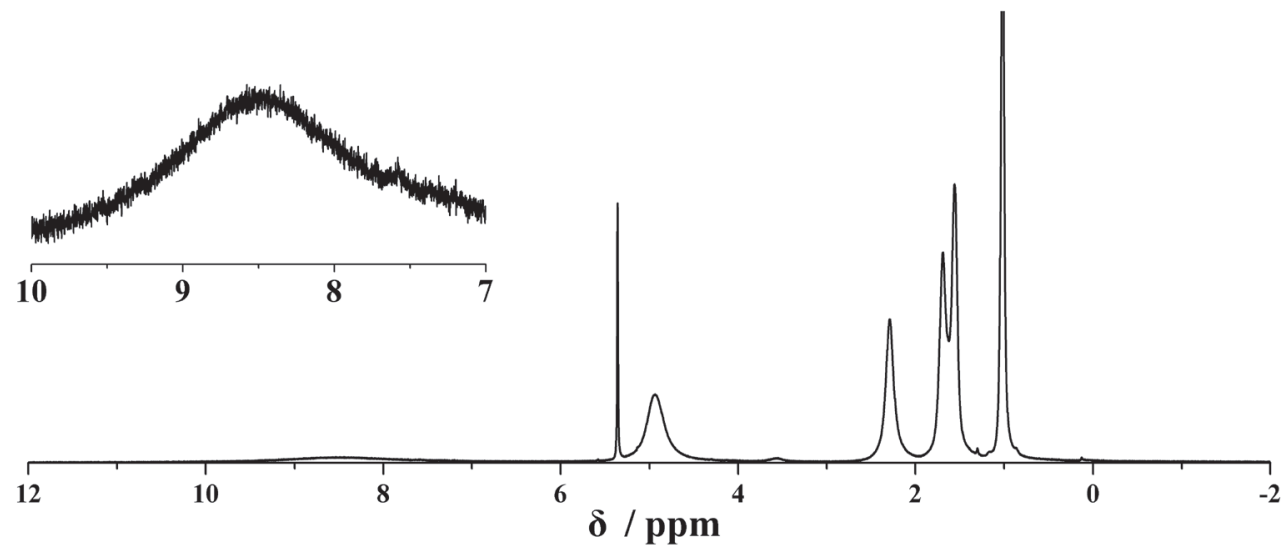

Figure 1. ${ }^{1} \mathrm{H}$ NMR spectra of 1 in $\mathrm{CD}_{2} \mathrm{Cl}_{2}$.
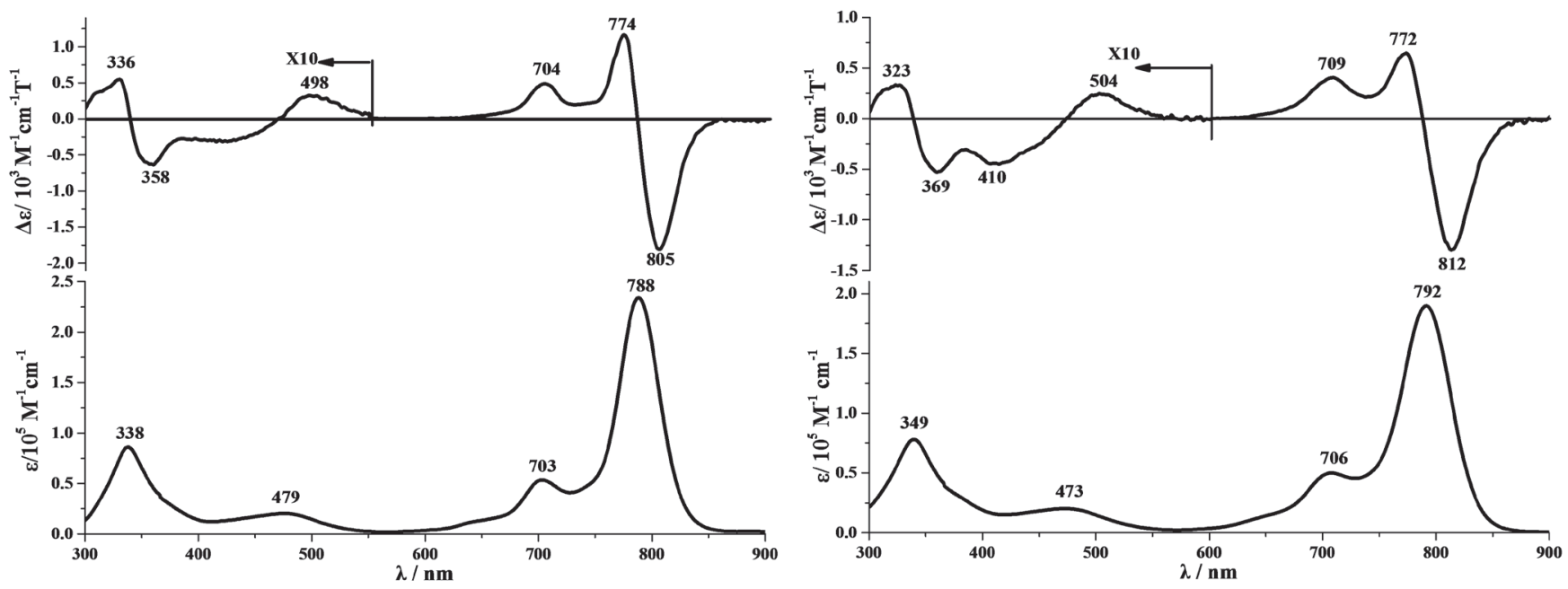

Figure 2. UV-vis absorption and $\mathrm{MCD}$ spectra of $\mathbf{1}$ in $\mathrm{CH}_{2} \mathrm{Cl}_{2}$ (up) and DMF (bottom).

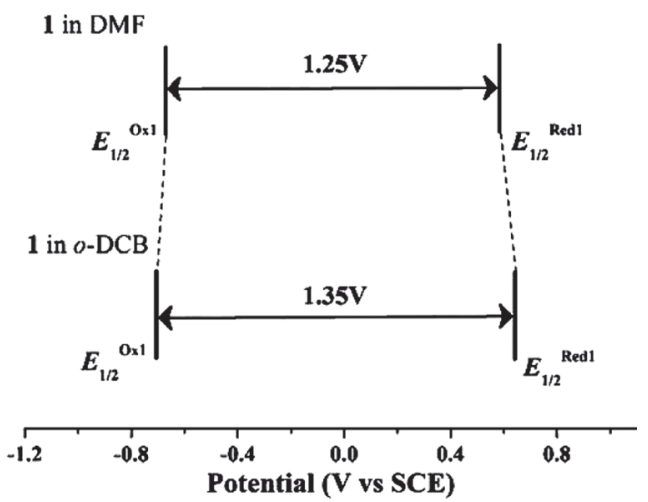

Scheme 1. Energy difference of electrochemistry measurements in low-polar $o$-DCB and polar DMF of oxo-V(IV)Pc.

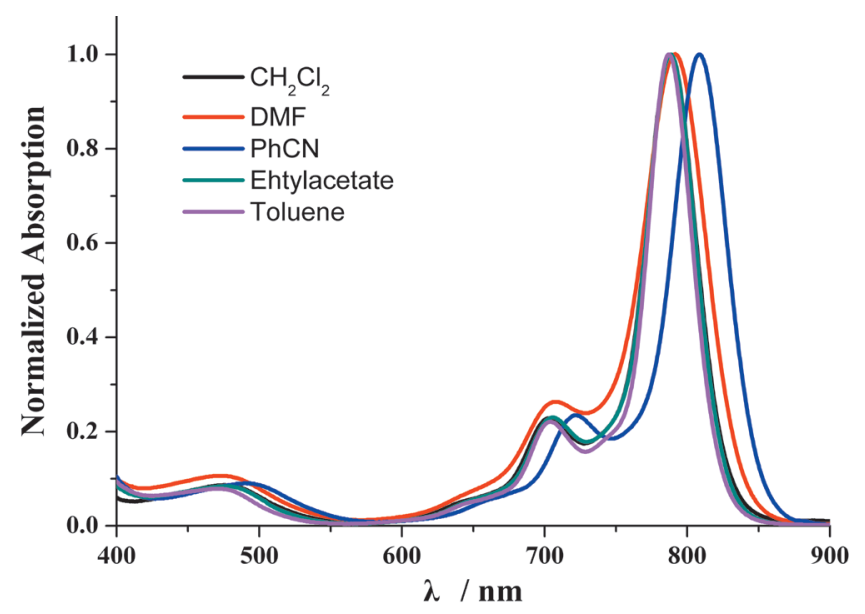

Figure 3. Q-band absorptions of UV-vis spectra of oxo-V(IV)Pc in various organic solvents. 

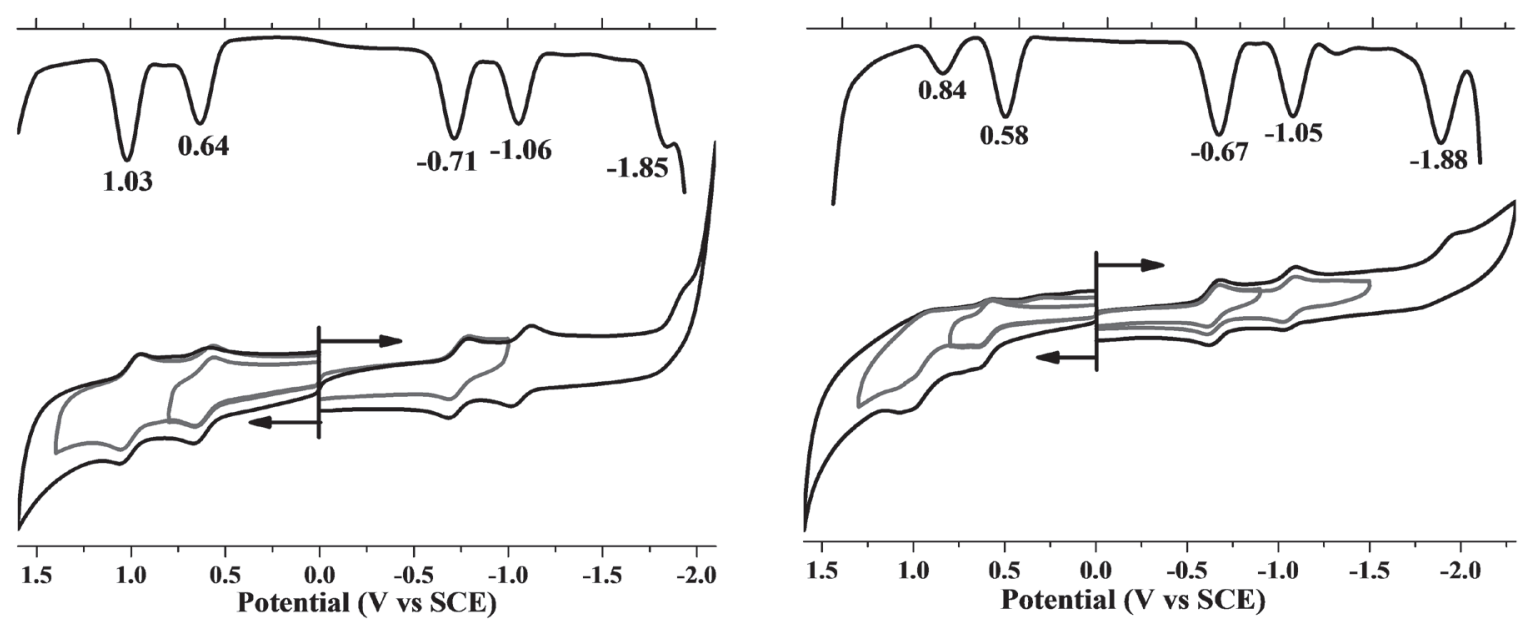

Figure 4. Cyclic voltammetry (CV) and DPV measurements of oxo-V(IV)Pc in $o$-dichlorobenzene (left) and DMF (right).
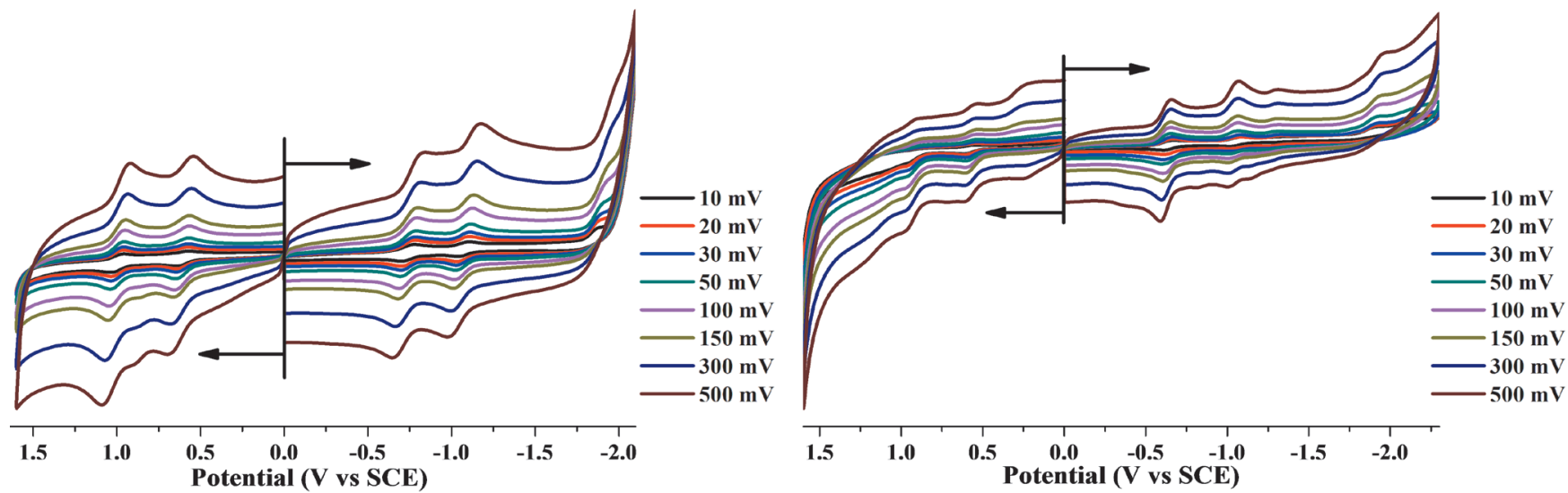

Figure 5. Multi-scan rate of cyclic voltammetry (CV) measurements of oxo-V(IV)Pc in $o$-dichlorobenzene (left) and DMF (right).

Table 1. Values of Q-band UV-vis absorptions of oxo-V(IV)Pc in various solvents.

\begin{tabular}{cccccc}
\hline & $\mathrm{CH}_{2} \mathrm{Cl}_{2}$ & Toluene & Ethylacetate & DMF & PhCN \\
\hline Oxo-V(IV)Pc 1 & $788 \mathrm{~nm}$ & $787 \mathrm{~nm}$ & $789 \mathrm{~nm}$ & $792 \mathrm{~nm}$ & $810 \mathrm{~nm}$ \\
\hline
\end{tabular}

Table 2. Electrochemistry measurements of various oxo-V(IV)Pc derivatives.

\begin{tabular}{|c|c|c|c|c|c|c|c|}
\hline \multirow{2}{*}{ Molecular Structure } & \multicolumn{4}{|c|}{ Reduction } & \multicolumn{3}{|c|}{ Oxidation } \\
\hline & Solvent & $\mathrm{V}^{\mathrm{II}} \mathrm{Pc}^{-2} / \mathrm{V}^{\mathrm{III}} \mathrm{Pc}^{-3}$ & 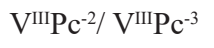 & $\mathrm{V}^{\mathrm{II}} \mathrm{Pc}^{-3} / \mathrm{V}^{\mathrm{III}} \mathrm{Pc}^{-4}$ & $\mathrm{~V}^{\mathrm{II}} \mathrm{Pc}^{-3} / \mathrm{V}^{\mathrm{III}} \mathrm{Pc}^{-4}$ & $\mathrm{~V}^{\mathrm{III}} \mathrm{Pc}^{-3} / \mathrm{V}^{\mathrm{III}} \mathrm{Pc}^{-4}$ & Ref. \\
\hline Oxo-V(IV)Pc & $o$-DCB & -1.85 & -1.06 & -0.71 & 0.64 & 1.03 & This work \\
\hline $\mathrm{OV}\left[\mathrm{Pc}(\mathrm{Bu})_{4}\right]$ & $\mathrm{CH}_{2} \mathrm{Cl}_{2}$ & - & -1.08 & -0.58 & 0.94 & - & {$[16]$} \\
\hline $\mathrm{OV}\left(\mathrm{PcF}_{16}\right)$ & $\mathrm{CH}_{2} \mathrm{Cl}_{2}$ & -1.41 & -0.62 & -0.29 & $0.85^{\mathrm{a}}$ & - & [17] \\
\hline $\mathrm{OV}\left[\mathrm{Pc}\left(\mathrm{SC}_{5} \mathrm{H} 11\right)_{8}\right]$ & $\mathrm{CH}_{2} \mathrm{Cl}_{2}$ & -1.14 & -0.89 & -0.54 & 0.68 & 1.02 & {$[18]$} \\
\hline Oxо-V(IV)Pc & DMF & $-1.88^{\mathrm{a}}$ & -1.05 & -0.67 & 0.58 & 0.84 & This work \\
\hline $\mathrm{OV}\left[\mathrm{Pc}\left(\mathrm{OC}_{6} \mathrm{H}_{3}(t-\mathrm{Bu})_{2}\right)_{4}\right]$ & DMF & -2.07 & -1.12 & -0.62 & 0.76 & 1.21 & {$[19]$} \\
\hline $\mathrm{OV}\left[\mathrm{Pc}\left(\mathrm{C}_{8} \mathrm{H}_{17}\right)_{4}\right]$ & DMF & -1.94 & -0.97 & -0.51 & 0.94 & 1.34 & [19] \\
\hline
\end{tabular}

a: irreversible processes 

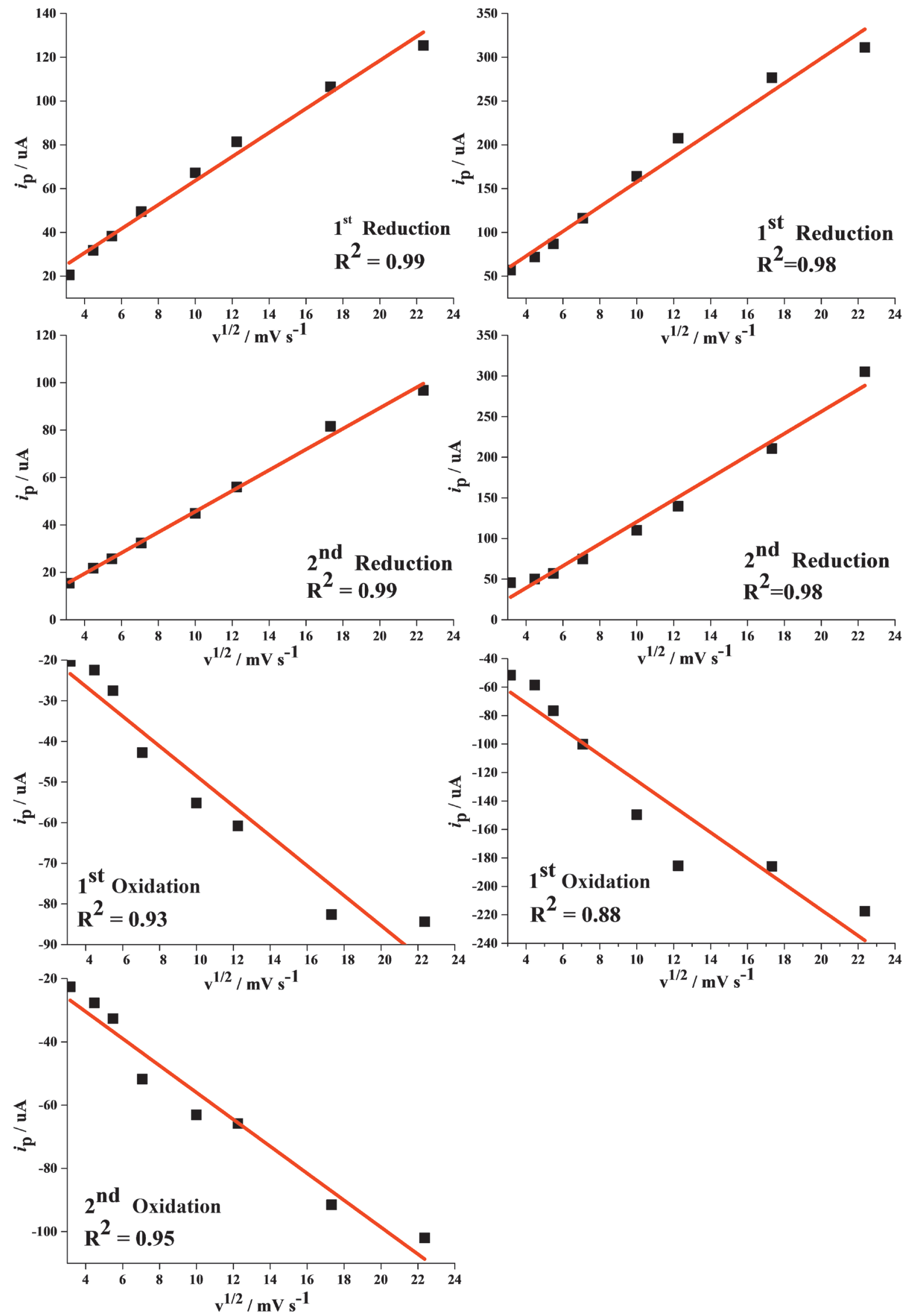

Figure 6. The dependence of square root of the scan-rate $\left(\mathrm{v}^{1 / 2}\right)$ on the peak current $\left(i_{\mathrm{p}}\right)$ for the all oxidations and reductions of oxo- $\mathrm{V}(\mathrm{IV}) \mathrm{Pc}$ in $o$-dichlorobenzene (up) and DMF (bottom) containing 0.1 M TBAP. 


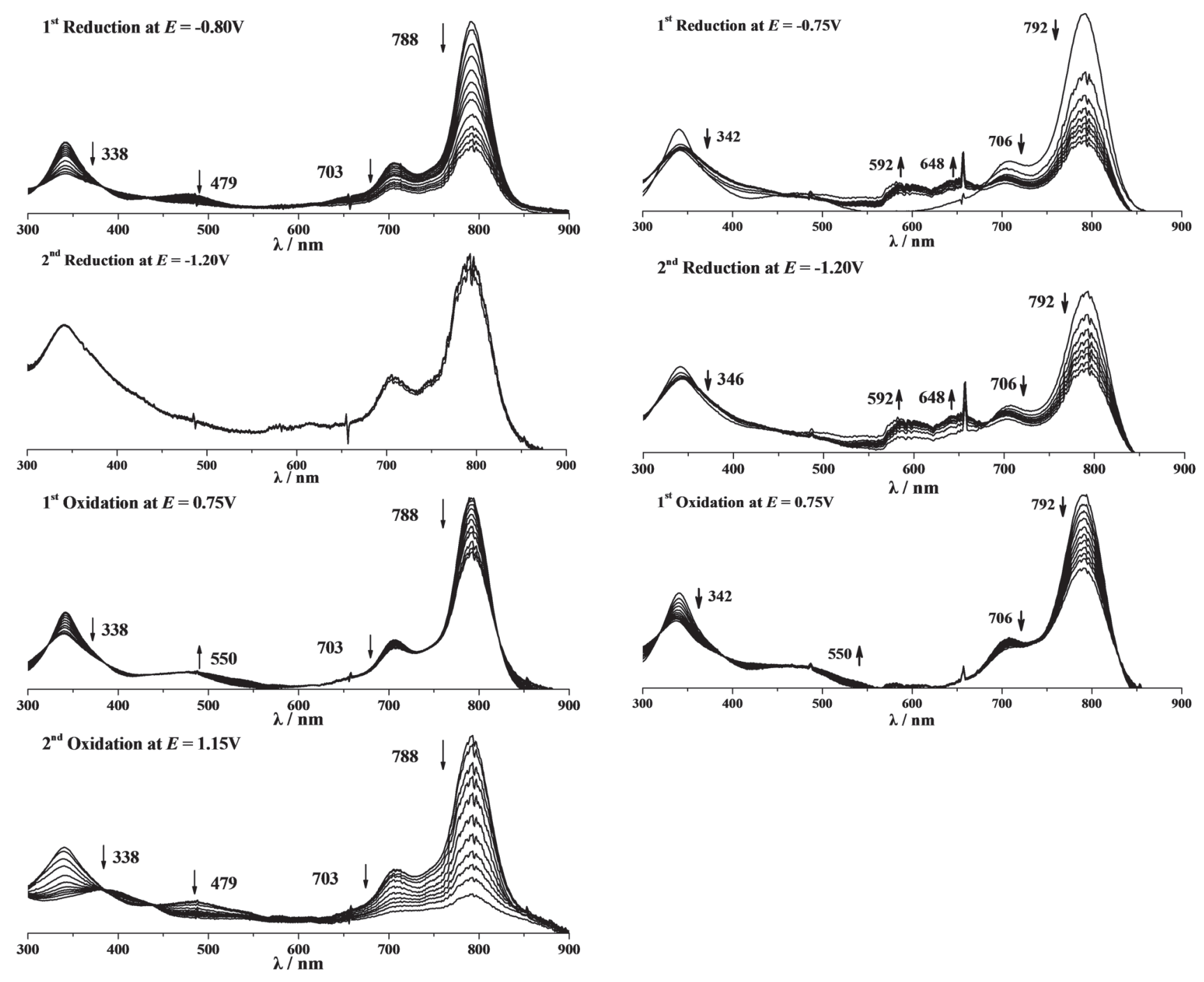

Figure 7. Thin-layer UV-visible spectral changes obtained during the second reduction and/or oxidation of oxo-V(IV)Pc in $o$-dichlorobenzene and DMF.

\section{Conclusions}

A oxo-V(IV)Pc having main absorption band at NIR region has been synthesized and characterized. Solvent dependent spectroscopy, electrochemistry and spectroelectrochemistry studies were carried out including UVvis, magnetic cicular dichroism (MCD) spectra, CV, DPV, multi-scan rate $\mathrm{CV}$ and thin-layer spectroelectrochemistry to give detailed understanding the effect of the substituents and solvent polarities on the electronic structures of this near-infrared oxo-V(IV)Pc. Considered NIR phthalocyanines have a wide range of potential applications in various high-tech fields, such as NIR optical recording materials and in IR radiation filters. The studies about solvent dependent electronic structure provide useful information for future rational molecular design, characterization, and potential applications.

Acknowledgements. Financial support was provided by the National Scientific Foundation of China (No. 21171076).

\section{References}

1. (a) Mack J., Kobayashi N. Chem. Rev. 2011, 111, 281-321; (b) Claessens C.G., Hahn U., Torres T. Chem. Rec. 2008, 8, 75-97; (c) Jiang Y., Li M.Z., Liang X., Mack J., Wildervanck M., Nyokong T., Qin M.F., Zhu W.H. Dalton Trans. 2015, 44, 18237-18246; (d) Gao Y., Chen Y., Li R., Bian Y., Li X., Jiang J. Chem. Eur. J. 2009, 15, 13241-13252; (e) Wang R., Li R., Li Y., Zhang X., Zhu P., Lo P., Ng D.K.P., Pan N., Ma C., Kobayashi N., Jiang J. Chem. Eur. J. 2006, 12, 1475-1485. (f) Liu Q., Li Y., Liu H., Chen Y., Wang X., Zhang Y., Li X., Jiang J. J. Phys. Chem. C 2007, 111, 7298-7301. (g) Gao Y., Li R., Dong S., Bian Y., Jiang J. Dalton Trans. 2010, 39, 1321-1327; (c) Wohrle D., Meissner D. Adv. Mater. 1991, 3, 129-138; (h) Rostalki J., Meissner D. Sol. Energy Mater. Sol. Cells 2000, 63, 37; (i) Koeppe R., Sariciftci N.S., Troshin P.A., Lyubovskaya R.N. Appl. Phys. Lett. 2005, 87, 244102; (j) Torre G., Vazquez P., Agullo-Lopez F., Torres T. Chem. Rev. 2004, 104, 3723-3750.

2. (a) Linstead R.P., Whalley M.J. J. Chem. Soc. 1952, 48394846; (b) Shimizu S., Haseba Y., Yamazaki M., Kumazawa G., Kobayashi N. Chem. Eur. J. 2014, 20, 4822-4828; (c) Mack J., 
Sosa-Vargas L., Coles S.J., Tizzard G.J., Chambrier I., Cammidge A.N., Cook M.J., Kobayashi N. Inorg. Chem. 2012, 51, 12820-12833; (d) Donzello M.P., Ercolani C., Gaberkorn A.A., Kudrik E.V., Meneghetti M., Marcolongo G., Rizzoli C., Stuzhin P.A. Chem. Eur. J. 2003, 9, 4009-4024; (e) Ayhan M.M., Özpınar G.A., Durmuş M., Gürek A.G. Dalton Trans. 2013, 42, 14892-14904; (f) Safonova E.A., Martynov A.G., Nefedov S.E., Kirakosyan G.A., Gorbunova Y.G., Tsivadze A.Y. Inorg. Chem. 2016, 55, 2450-2459.

3. Bradbrook E.F., Linstead R.P. J. Chem. Soc. 1936, 1739-1744.

4. Freyer W., Minh L.Q. Monatsh. Chem. 1986, 117, 475-489.

5. The Porphyrin Handbook, Properties and Materials (Kadish K.M., Smith K.M., Guilard R., Eds.). New York: Academic Press, 2003, Chapter 17.

6. Christie R.M. Dyes Pigm. 1995, 27, 35-43.

7. (a) Lim B., Bloking J.T., Ponec A., McGehee M.D., Sellinger A. ACS Appl. Mater. Interfaces 2014, 6, 6905-6913; (b) Sun Y.Q., Liu J., Lv X., Liu Y.L., Zhao Y., Guo W. Angew. Chem. Int. Ed. 2012, 51, 7634-7636.

8. Eguchi K., Nakagawa T., Takagi Y., Yokoyama T. J. Phys. Chem. C 2015, 119, 9805-9815.

9. (a) Piepho S.B., Schatz P.N. Group Theory in Spectroscopy with Applications to Magnetic Circular Dichroism, New York: Wiley, 1983; (b) Mack J., Stillman M.J., Kobayashi N. Coord. Chem. Rev. 2007, 251, 429-453.
10. Leznoff M., Hu C.R., McArthur Y., Qin Y., van Lier J.E. Can J. Chem. 1994, 72, 1990-1998.

11. Kasuga K., Kawashima M., Asano K., Sugimori T., Abe T., Kikkawa K.T., Fujiwara T. Chem. Lett. 1996, 867-868.

12. Freyer W., Minh L. Q. J. Prakt. Chem. 1987, 329, 365-373.

13. (a) Stillman M.J., Nyokong T. In: Phthalocyanines: Properties and Applications, Weinheim: VCH, 1989, Chapter 3; (b) In: The Porphyrin Handbook (Kadish K.M., Smith K.M., Guilard R., Eds.). New York: Academic Press, 2003, Chapter 103; (c) Michl J. J. Am. Chem. Soc. 1978, 100, 6801-6811; (d) Michl J. J. Am. Chem. Soc. 1978, 100, 6812-6818; (e) Ceulemans A., Oldenhof W., Gçrller-Walrand C., Vanquickenborne L.G. J. Am. Chem. Soc. 1986, 108, 1155-1163.

14. Guo L., Ellis D.E., Hoffman B.M., Ishikawa Y. Inorg. Chem. 1996, 35, 5304-5312.

15. Ogunsipe A.O., Maree M.D., Nyokong T. J. Mol. Struct. 2003, 650, 131

16. Lever A.B.P., Milaeva E.R., Speier G. In: Phthalocyanines: Properties and Applications, New York: VCH Publishers, 1993, Vol. 3

17. Handa M., Suzuki A., Shoji S., Kasuga K., Sogobe K. Inorg. Chem. Acta 1995, 230, 41

18. Mbambisa G., Nyokong T. Polyhedron 2008, 27, 2799-2804.

19. Jiang Z., Ou Z. P., Chen N., Wang W., Huang J., Shao J., Kadish K.M. J. Porphyrin Phthalocyanines 2005, 9, 352. 